
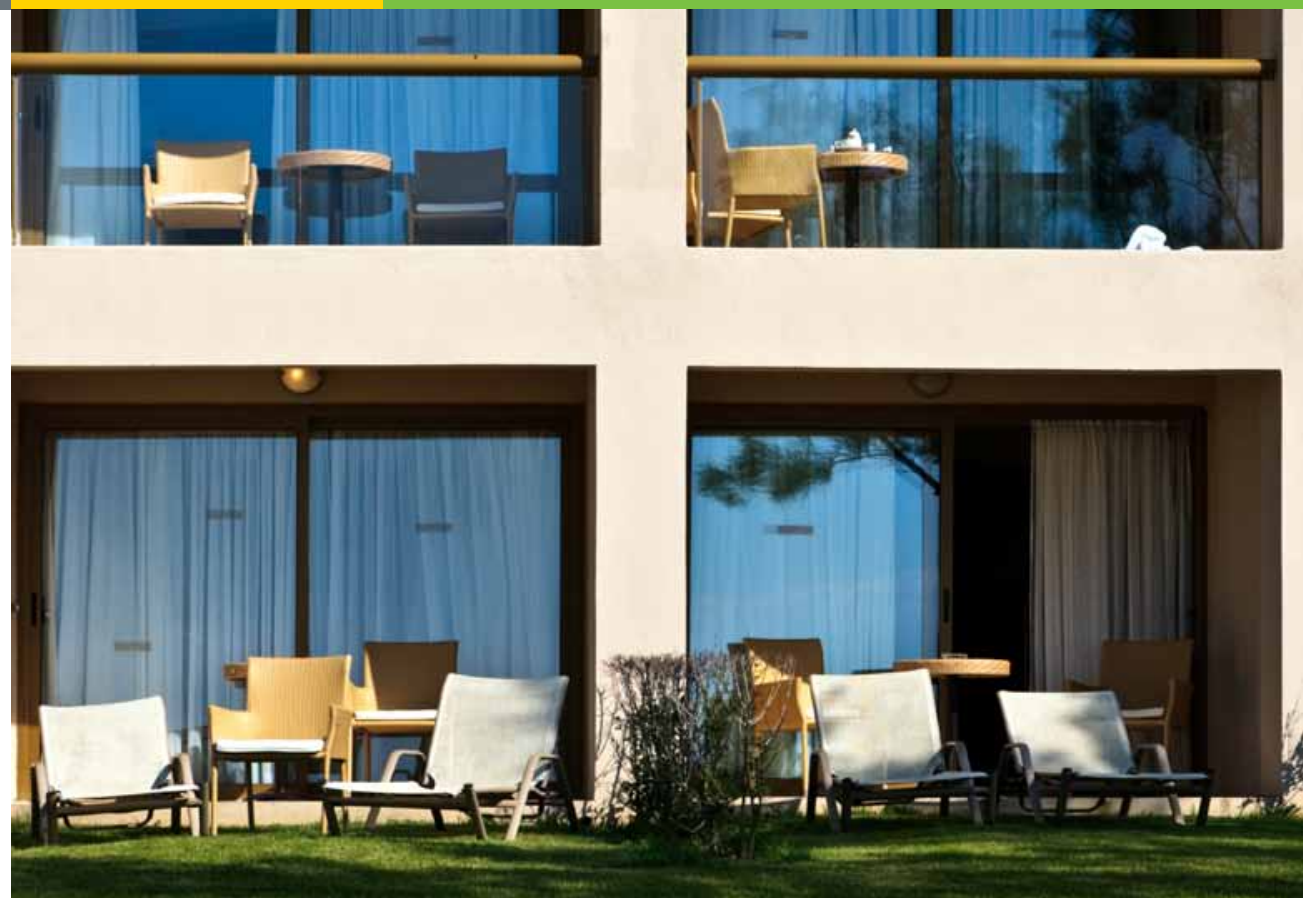

\title{
Assessing and Reducing Miscellaneous Electric Loads (MELs) in Lodging
}




\section{Assessing and Reducing Miscellaneous Electric Loads (MELs) in Lodging}

Prepared by

Pacific Northwest National Laboratory

Emily Rauch, Michael Baechler

Efficiency Solutions, LLC

Greg Sullivan

September 26, 2011

Prepared for

U.S. Department of Energy

under Contract DE-AC05-76RL01830

PNNL-21055

Pacific Northwest National Laboratory

Richland, Washington 99352

This report was prepared as an account of work sponsored by an agency of the

United States Government. Neither the United States Government nor any agency thereof, nor Battelle Memorial Institute, nor any of their employees, makes any warranty, express or implied, or assumes any legal liability or responsibility for the accuracy, completeness, or usefulness of any information, apparatus, product, or process disclosed, or represents that its use would not infringe privately owned rights. Reference herein to any specific commercial product, process, or service by trade name, trademark, manufacturer, or otherwise does not necessarily constitute or imply its endorsement, recommendation, or favoring by the United States Government or any agency thereof, or Battelle Memorial Institute. The views and opinions of authors expressed herein do not necessarily state or reflect those of the United States Government or any agency thereof. 


\section{Contents}

Overview.

1

Miscellaneous Electric Load Reduction Program Development 2

Miscellaneous Electric Load Strategies

by Lodging Industry Major Use Areas 5

Recommended Miscellaneous Electric Load

Energy Reduction Opportunities for the Lodging Industry.... 8

Recommended Miscellaneous Electric Load

Energy Reduction Strategies for the Lodging Industry 9

References 12

Resources. 12 


\section{Assessing} and Reducing Miscellaneous Electric Loads (MELs) in Lodging

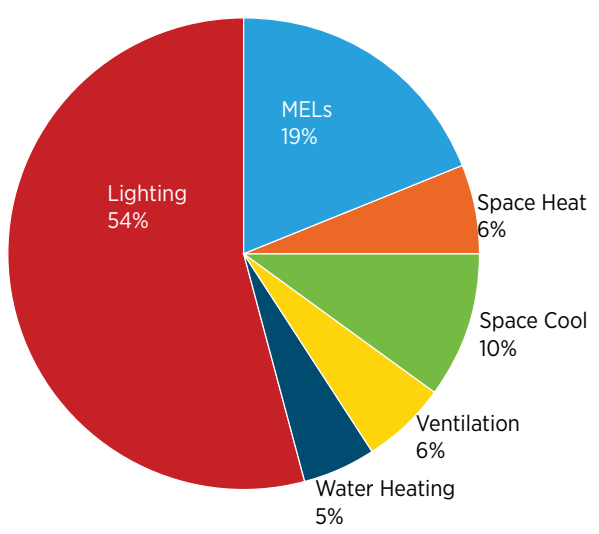

Lodging Industry Energy Shares as

Reported in the 2003 Commercial Building Energy Consumption Survey

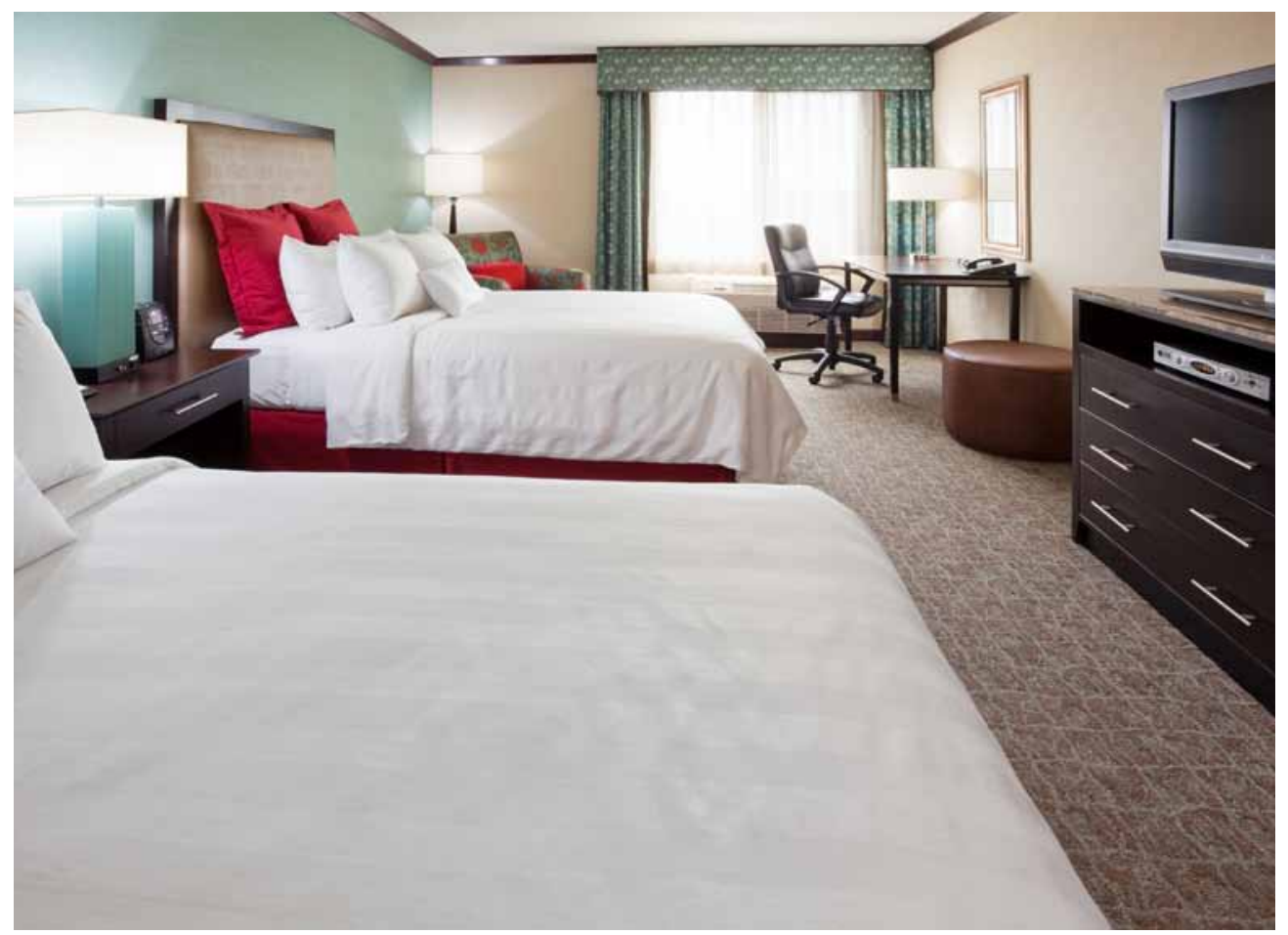

\section{Overview}

Miscellaneous electric loads (MELs) are the loads outside of a building's core functions of heating, ventilating, air conditioning, lighting, and water heating. MELs are becoming an increasing fraction of total building energy use. The explosive growth in products that plug into an outlet coupled with increasing efficiency in core building functions has made MELs a larger percentage of total building energy loads.

Taken across the entire commercial building sector, MELs now account for roughly $30 \%$ of the total energy use; this amounts to about $5 \%$ of all U.S. primary energy use (McKenney, 2010). Lodging industry MELs represent a significant portion of the total energy use. The pie chart to the left presents the relative energy shares within the lodging industry (CBECS 2003); as listed, MELs includes all non HVAC, lighting and water heating loads.

In the lodging industry, MELs include the following:

- Front desk, office, and kiosk computers and monitors

- Printers, faxes, and copiers

- Video displays including security monitors

- Televisions both in lobby and guest room areas
- ATMs

- Compact and full size refrigerators

- Vending equipment

- Ice machines

- Guest laundry 


\section{METERING MELS}

The first step in metering plug loads is

to select the right meter. At a

minimum, the meter should be able to

measure and log one week of electrical

power (Watts) data at a sampling

interval of 30 seconds. The meter

should be designed for the type of

circuit to be metered (e.g., 120 Volt, 15

amp, 60 Hertz). Also, the MELs in office

buildings are numerous and varied, so

the meter should be able to accurately

meter loads of 0-1800 W. Other

desirable features include an external

display, an internal clock that

timestamps each data point, an

Underwriters Laboratories listing, and

a way to transmit data to a local or

remote repository.

The typical steps to meter a given plug

load are:

1. Set up the meter to measure electrical power only at a sampling interval of 30 seconds.

2. Power down and unplug the device to be metered.

3. Plug the device into the meter. Plug the meter into an outlet.

4. If necessary, clear the memory on the meter and go through any other initial setup, such as setting the date and time.

5. Power on the device to be metered.

6. Meter the device for an entire typical work week. During that period, use the device as normal.

7. Calculate the average occupied and unoccupied hours load.
While some lodging organizations have full-service restaurants supported by commercial kitchens, this guide will focus on the non-restaurant loads common to most of these establishments with general guidance on addressing these energy intensive areas.

\section{Miscellaneous Electric Load Reduction Program Development}

Reducing MELs in a lodging setting requires both local and corporate action. Corporate action centers on activities to prioritize and allocate the right resources to correct procurement and central control issues. Local action includes branch assessment or audits to identify specific loads and needs. The worksheet at the end of this guide can help with cataloging needed information and estimating savings potential. The following steps provide a guide to MEL reductions in the lodging industry. The general process has been adapted from a process developed for office buildings by the National Renewable Energy Laboratory (NREL 2011).

\section{Step 1: Establish a Plug and Process Loads Champion and Team}

The first step in addressing MELs in a low-energy building is to establish a MEL champion (or a team of champions) to initiate and help with the process. This person needs to understand technical energy efficiency opportunities and design strategies and be able to apply business model cost justifications. He or she must be willing and able to question the owner's operations, institutional policies, and procurement processes. Team members working with the champion may include on-site lodging staff and representatives from key corporate functions such as information technology (IT) and branding.

\section{Step 2: Develop a Business Case for Addressing Plug and Process Loads}

To gain buy-in from all parties involved, especially the building owner (franchisee), the champion must develop a business case for addressing MELs. In many projects, the business case will be the energy and cost savings associated with each strategy. The projects will also need to address how the change could either positively or negatively affect the guest experience. The business case gives all parties a financial incentive to investigate MELs and pay close attention to items common to guest rooms and the large load, low quantity equipment in common spaces or back of the house areas.

\section{Step 3: Benchmark Current Equipment and Operations}

An energy audit needs to be performed to establish a baseline of MELs and operations. The audit may include metering to measure specific loads and to establish operating schedules. The sidebar on the left describes the metering process. Manufacturers' specification sheets can be helpful in determining specified loads. The worksheet at the end of this document can assist in site energy audits. The audit should include a survey of equipment contributing to MELs. Important data to collect include the following:

- Equipment type, make, model and age.

- Equipment nameplate energy use data, e.g., watts used during different modes of operation (if listed).

- Daily utilization schedules - short of having metered data, these are best observed as how often equipment is fully energized yet not use.

Once collected, these data should be assembled and grouped by either equipment type (e.g., all office computers) or area of use (e.g., break room/kitchen area). These groupings will be used to assess the potential for efficiency improvements by group or area. 


\section{Step 4: Identify "True" Needs}

Assess employee and hotel guest "true" needs. A true need, as opposed to a perceived need, is required to achieve business goals while meeting guest expectations for quality and comfort. Determining both employee and hotel guest needs will reveal any nonessential equipment that may be taken out of service.

To reduce MELs, the MEL champion must be willing to understand what employees produce as part of their jobs and what tools they require, but must also be diplomatic enough to help them do their jobs energy efficiently without making them feel their purposes are being questioned. Every employee, including those working with sensitive information (e.g., security, management), must be accounted for. Each of these staff are potential allies in finding better ways to successfully accomplish tasks.

The MEL champion must also understand the business aspect of running a lodging establishment and maintaining a high level of guest satisfaction. The champion should evaluate how the equipment in common spaces is used by the guests and evaluate if there is an opportunity to condense these services or repurpose spaces to meet a new need for the guests. Some of the equipment in the guest rooms may be able to be downsized, more efficient, or controlled in such a way that does not impact guest satisfaction.

\section{Step 5: Meet Needs Efficiently}

Once the list of true occupant employee, hotel guest, and institutional needs is determined, each must be met as efficiently as possible and combined with accurate use scheduling.Simply specifying ENERGY STAR ${ }^{\circledR} h t t p: / / w w w . e n e r g y s t a r . g o v /$ and EPEAT $^{\circledR} h t t p: / / w w w$.epeat.net ${ }^{1}$ equipment should be done at a minimum. To gain more efficiency, the available equipment lists should be thoroughly reviewed and the most efficient equipment should be specified. Non-rated equipment must be researched to find the most efficient model, which should be turned off when not in use, if possible. Parasitic loads (energy that is being used while device is turnedoff, but still plugged in) require special attention, even if the equipment is energy efficient. There will always a more efficient way to perform operations. This is accomplished by using more efficient equipment in a more efficient manner.

\section{Step 6: Turn It All Off}

A key strategy in any MEL reduction program is to reduce energy when rooms and other spaces are not in use. Much of the energy used during non-occupied hours is generally wasted energy.

\section{Step 7: Adopt Corporate Policies}

The day-to-day energy efficiency of any building depends largely on the decisions of employees, hotel guests, facility managers, and owners, all of whom play key roles in whole-build ing energy consumption. For persistence of MELs savings a policy commitment should be made starting with corporate management and carried through

to branch management and staff. Recruit and engage corporate leaders in areas such as IT, branding, and facilities management to help innovate and implement new processes and products. Policy directives should be enacted with the following goals:

- Equipment procurement - establish procurement guidelines for all MELs equipment of ENERGY STAR ${ }^{\circledR}$ of better. When equipment is not rated by ENERGY STAR $^{\circledR}$, choose the most efficient models.

- Ancillary/personal electronic equipment - establish and enforce policies to eliminate the use of non-company issued equipment (e.g., space heaters, coffee makers, refrigerators, etc.) by employees. 


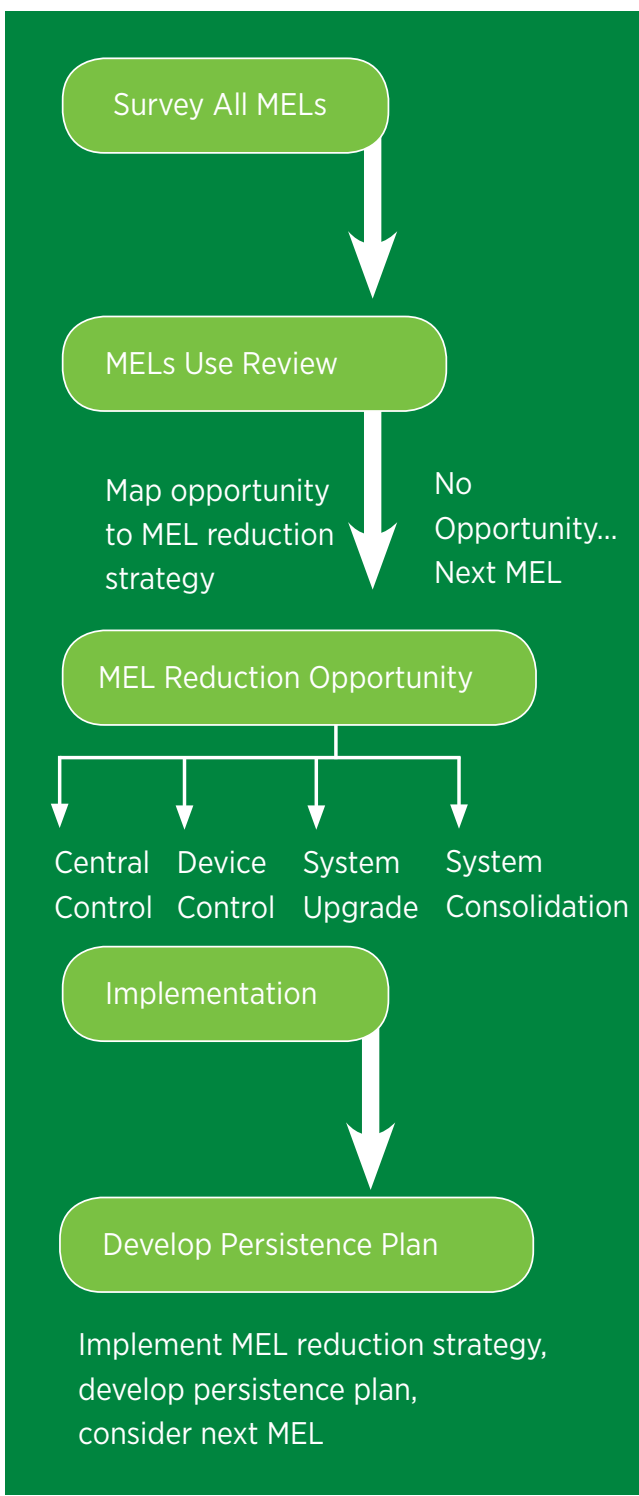

Flow diagram showing the process for Steps 3-10.
- Employee and Guest education - because MELs savings rely on staff and guest interaction and awareness, an educational program should be developed to highlight activities and recognize actions and staff.

- MEL controls - establish a policy to install hotel key card switches in major renovations and new construction. These switches can be wired to off anything on a wall receptacle including TVs and miscellaneous lighting.

\section{Step 8: Address Unique Miscellaneous Electric Loads}

Some equipment is not specified by the building owners or hotel employees. For example, outside vendors typically control restaurant areas. For such situations, the building owner should contractually require or provide the most efficient equipment available.

\section{Step 9: Promote Awareness}

A crucial step in designing MELs for a low-energy building is to promote awareness of efficiency measures and best practices to both employees and guests, because MEL energy use is largely dictated by occupant behavior. Energy conservation awareness has been shown to have a significant impact on energy use and could be incorporated alongside the water conservation campaigns ongoing at many lodging franchises.

\section{Step 10: Address Plug and Process Loads in Design}

New construction and renovation projects bring additional MEL reduction op portunities that the design team should address. The design team should question standard specifications, operations, and design standards that limit energy savings opportunities. One key role the design team plays in reducing MELs is maximizing space efficiency. This strategy increases the ratio of employee and guest use per building area or piece of equipment. By implementing space efficiency, the amount of equipment in the building is decreased. Food prep areas, back office areas, and hallway beverage service areas typically have a high MEL density. With increased space efficiency, the number of these areas is decreased, equipment is more efficiently used, and MELs are reduced.

The design team has the opportunity to further reduce energy use by integrating MEL control strategies into the building's electrical system. Early in the design phase, the design team can build features into the electrical system to control the outlets at workstations, guest rooms, and in common areas. This strategy can be as simple as installing switches, vacancy sensors, or timed disconnects for outlets, or as sophisticated as controlling outlets through the building management system.

The design team is typically responsible for specifying equipment such as elevators and transformers. Before elevators are specified, the stairs should be designed to be as inviting and convenient as possible. Elevators should then be carefully scrutinized to find the most efficient model. Some important features to look for are occupancy-controlled lighting and ventilation, and smart scheduling. Some projects may require the design team to specify general appliances such as refrigerators, dishwashers, and drinking fountains. To achieve greater energy savings, the most efficient equipment models must be specified. 


\section{Miscellaneous Electric Load Strategies by Lodging Industry Major Use Areas}

Strategies for affecting the energy use of MELs fall into one of four main categories:

- Central Control. With careful planning MELs be controlled from a remote location. Central control options include programmed control at the electrical service panel (motorized electrical breakers), control using a building automation/energy management system, or control over a network interface.

- Device-Level Control. The stand-alone control of MEL devices can offer efficiency savings through optimized device "on-time." Stand-alone control devices include equipment timers and/or occupancy-based controllers. These are generally focused on non-critical systems and appliances such as computer monitors and certain types of vending machines.

- Equipment Upgrade. With technology advances, notably in high-efficiency power supplies and electronic controls, many new MELs are benefitting from reduced power needs. Depending on power costs, some equipment may be cost-effective in an "early-replacement" scenario versus the typical "end-of-life" replacement.

- System Consolidation/Equipment Removal. There are certain MELs that lend themselves well to consolidation from numerous distributed (smaller) devices to one or a few centrally located (larger) devices. Included in this category are printers, faxes, and compact refrigerators.

The costs associated with improving MELs efficiency will vary with MEL and proposed strategy.

The central control strategy represents one of the most cost-effective MELs efficiency measure because of its potential to affect multiple systems with a single point of implementation. This measure is often applied to computers and other ancillary business equipment that are left on during non-business hours. Costs associated with this measure relate to the technologies that affect central control; dedicated circuit control, building automation, or networked services. Paybacks on the order of 2 years or less are common depending on the MEL and control type.

Controlling MELs at the device level offers the economic benefit of being selective in application and used in situations where central control is not an option. Capital costs of device-level control systems range from under $\$ 5$ (timers) to about $\$ 100$ (occupancy-based controllers). Paybacks vary with device controlled, but are typically under 3 years.

The equipment upgrade strategy can be the most capital-intensive option, but also may have the greatest energy savings potential. Costs associated with this option are directly related to the device being upgraded. The economics of this option are dictated by the remaining useful life of equipment being replaced. If the old equipment required replacement, the increment cost (efficient over standard technology) can be nominal resulting in a very quick payback. If replacement requires early retirement, the incremental cost should include the value of the remaining equipment life and can result in longer paybacks. 
There is no better energy savings strategy than removing a connected load from a building's energy demand. The system consolidation/equipment removal strategy eliminates equipment through a consolidation approach. The capital cost and resulting economics depend on the type and numbers of equipment consolidated and the remaining useful life on equipment being replaced, but when distributed equipment such as printers or compact refrigerators are replaced with an efficient central device, the paybacks may be measured in months.

Strategies for specific areas are described in the following sections.

\section{Lobby Area/Front Desk}

Lobby areas typically offer many self-service amenities to guests. These amenities usually include free coffee, internet kiosks, and seating areas with televisions. While these amenities have importance to the overall guest experience, they also offer opportunities to make equipment- and operational-efficiency decisions.

Equipment and systems at the front desk need to be customer-ready (i.e., no time spent waiting for systems to regenerate from sleep states), but that doesn't preclude efficiency opportunities. All relevant lobby/front desk area devices should be specified as ENERGY STAR or better and, when appropriate, be included in electric load management best practices, e.g., occupancy-based operation and night/offhour shutdown protocols.

\section{Office Areas}

Lodging office-area MEL use is typically dominated by desktop computers, monitors, printers, and fax/scanner devices. All these devices should be upgraded to ENERGY STAR listed equipment.

A standard desktop computer and monitor will use on average of between 350 - $450 \mathrm{kWh}$ per year. Replacing desktop computers with the latest high-efficiency models can save between $100-300 \mathrm{kWh}$ per year. It is also important to set the power options to save energy when the computer is not in use. Computers that sit idle or run screensavers when they are not being used waste considerable energy. The power options should be set so that the computer and monitor(s) go into standby or sleep mode after 15 minutes of idle time. The following figure shows the proposed benefit of installation of new efficient desktop computers.

Sample Energy Savings Potential From the Replacement of an Office Computer with a High-Efficiency Computer - 135 kWh/yr

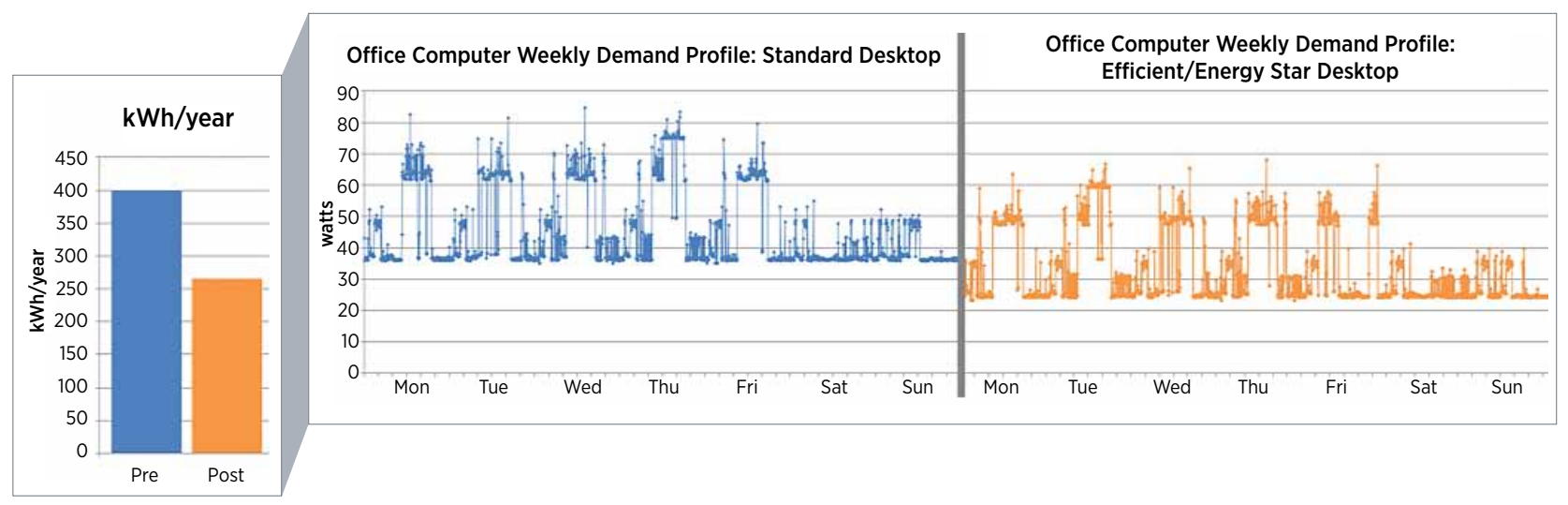


Monitors are the next-largest energy use in the hotel office areas. Replacing old monitors with energy-efficient liquid crystal display (LCD) monitors saves energy. To achieve the greatest savings, light-emitting diode (LED) backlit LCD monitors should be used. The first figure below shows energy savings from adding a device level control to a computer monitor. The second figure shows the savings from adding a central control to a single computer.

\section{Meeting/Conference Room Equipment}

By their nature, meeting and conference rooms can have widely varying uses and schedules. A key to MEL energy use reduction is to implement controls that disconnect or turn off equipment when the space is unoccupied. Occupancy-based electrical controllers can be used to power down equipment during unoccupied and non-business hours. In addition to load control, the equipment installed in conference rooms should be energy efficient and ENERGY STAR listed where available.

\section{Network/Server Room}

Strategies within hotels network and server rooms focus on the procurement of the highest efficiency components, these include:

- Blade servers with energy-efficient power supplies and variable-frequency fans

- Uninterruptible power supplies with ratings of $95 \%$ efficiency

- ENERGY STAR rated monitors

\section{Common Areas, Break, and Lunch Rooms}

One of the largest single MEL opportunities is with refrigerators; inefficient refrigerators should be replaced with the most efficient and properly sized ENERGY STAR refrigerators. It is important to remove all personal compact-refrigerators and underused full-size refrigerators. A compact-refrigerator can use the same energy as a full-size refrigerator and an empty refrigerator can use as much or more energy than a full one.

\section{Sample Energy Savings Potential from Occupancy-Based Device-Level Control of a} Computer Monitor - $210 \mathrm{kWh} / \mathrm{yr}$

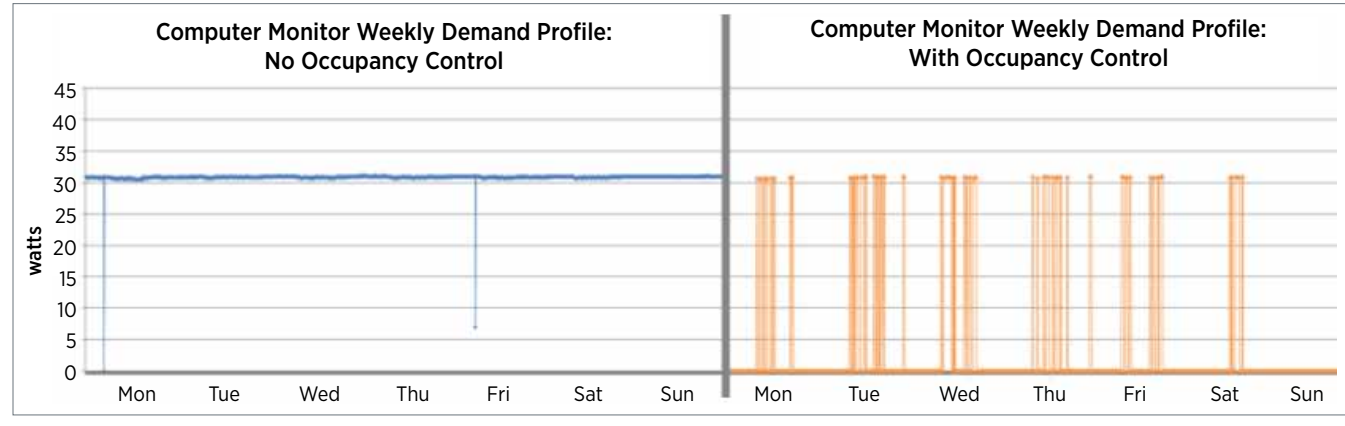

Sample Energy Savings Potential from Central Control (Night Shutdown) of an Office Computer - $180 \mathrm{kWh} / \mathrm{yr}$

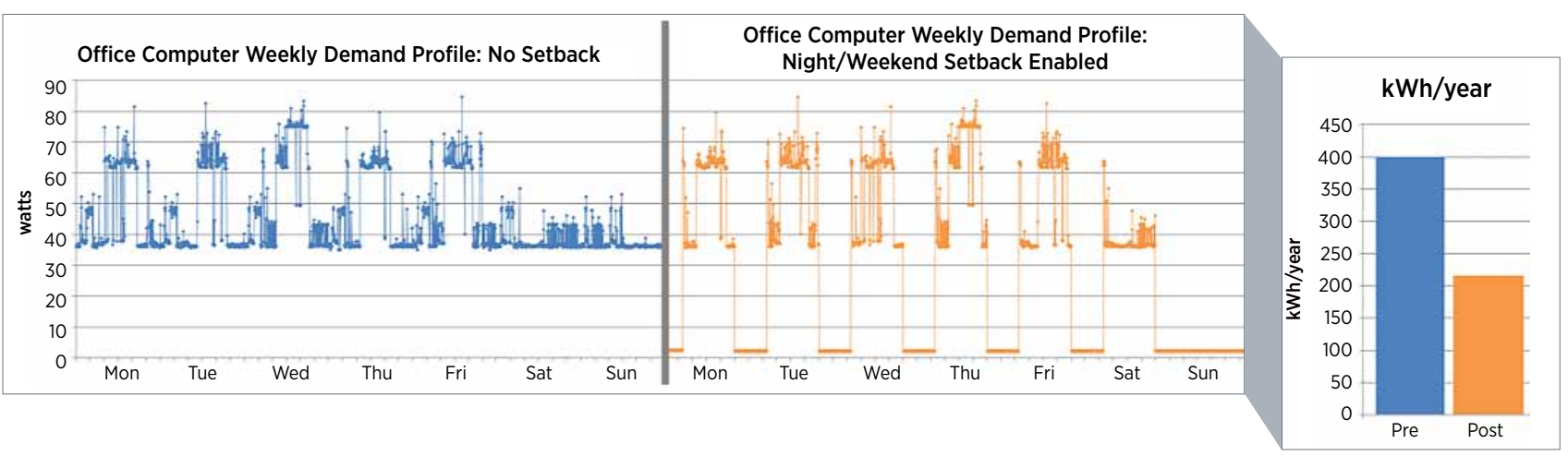


Items such as coffee pots, toasters, and microwaves should be upgraded with units that have limited standby energy use from any lights or displays. In many cases, the lights and displays are not needed and waste energy. These items make good candidates for powering electrical outlet timers so they are powered down during unoccupied hours.

Vending machines can consume as much or more than a full-size refrigerator. The first step in vending machine savings is to remove underused equipment and to replace aging, inefficient vending machines with the most efficient ENERGY STAR models. Removing the display lighting yields additional energy savings. Ice machines are significant energy users and should also be specified as ENERGY STAR or better.

\section{Guest Rooms}

Guest comfort and convenience are critical to the lodging industry. Opportunities in guest rooms focus on high-efficiency equipment including TVs and refrigerators. Both of these devices should be specified as ENERGY STAR or better during the procurement process. The figure below shows the estimated energy savings potential from installing high-efficiency guest room compact refrigerators.

\section{Security Monitors}

All old cathode ray tube (CRT) style security monitors should be replaced by LCD monitors.

Sample Energy Savings Potential from the Replacement of a Guest Room Refrigerator with a High-Efficiency Refrigerator - $70 \mathrm{kWh} / \mathrm{yr}$

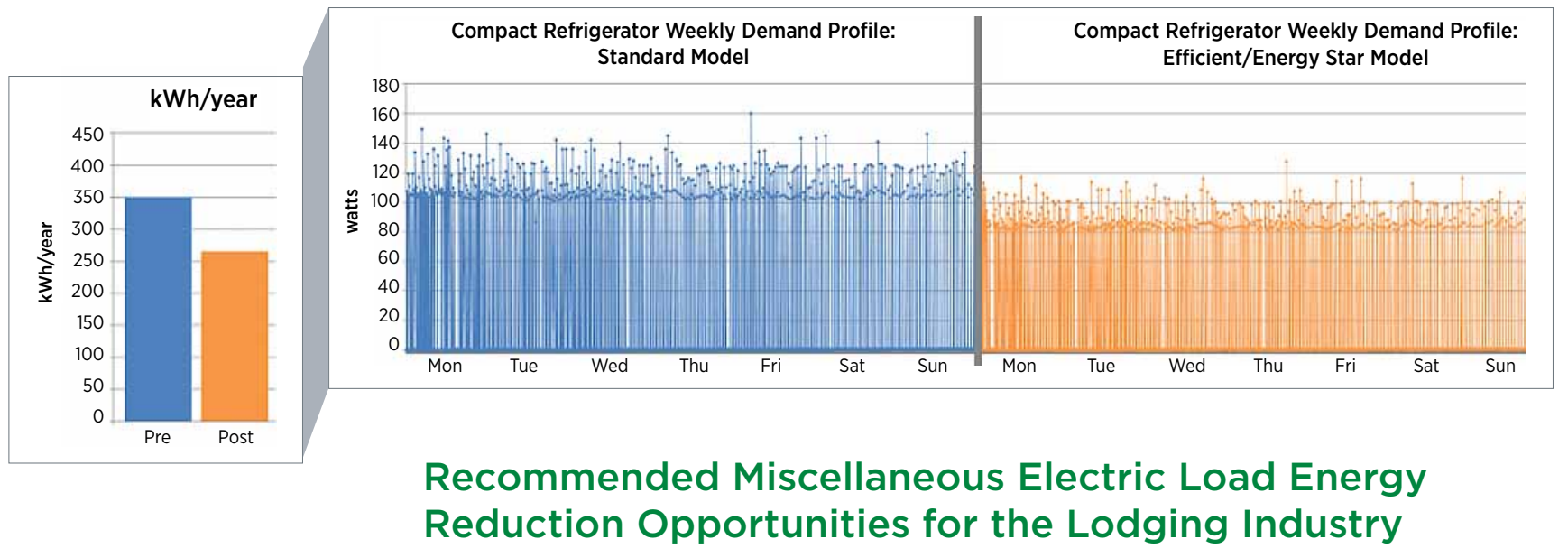

The below worksheet was developed to help identify potential energy savings by reducing MELs - Step 3 in Lodging Industry Assessment section.

For each strategy listed below, answer the question "Is your building doing this?" If the response is "NO" for any strategy, fill out the adjacent cells to the right to determine the total approximate savings that the given strategy could yield. Strategies that are listed without savings numbers are highly variable depending on the office building being assessed.

Data used to generate the savings values are from references: Deru, M., 2003; ECOS 2011; Esource 2008; Frank, S., 2010; Lobato, C., 2011; McKenney, K. 2010; NREL 2011; Navigant Consulting 2009; TIAX 2004. 


\section{Recommended Miscellaneous Electric Load Energy Reduction Strategies for the Lodging Industry}

\begin{tabular}{|c|c|c|c|c|c|c|c|}
\hline \multirow[b]{2}{*}{ Strategies } & \multicolumn{3}{|c|}{$\begin{array}{l}\text { Is your } \\
\text { building } \\
\text { doing this? }\end{array}$} & \multicolumn{4}{|c|}{$\begin{array}{l}\text { If you answered "NO," fill out these columns to determine the approximate savings } \\
\text { in your building }\end{array}$} \\
\hline & YES & NO & N/A & \multicolumn{2}{|c|}{$\begin{array}{l}\text { Savings for } 1 \text { Piece of Equipment } \\
\text { in kWh/year saved }\end{array}$} & $\begin{array}{l}\text { Quantity in } \\
\text { Your Building }\end{array}$ & $\begin{array}{l}\text { Total Approx. Savings } \\
\text { for Your Building }\end{array}$ \\
\hline \multicolumn{8}{|l|}{ Lobby Area } \\
\hline \multicolumn{8}{|l|}{ Customer Kiosk Computer } \\
\hline $\begin{array}{l}\text { Replace existing customer kiosk and business of- } \\
\text { fice computers with high-efficiency/ENERGY STAR } \\
\text { desktop computers. }\end{array}$ & $\square$ & $\square$ & $\square$ & $\begin{array}{l}135 \mathrm{kWh} / \text { year for each Kiosk computer } \\
\text { replaced with an ENERGY STAR model }\end{array}$ & $135 x$ & & \\
\hline \multicolumn{8}{|l|}{ Computer Monitor } \\
\hline Replace CRT monitors with LED backlit monitors. & $\square$ & $\square$ & $\square$ & $\begin{array}{l}100 \mathrm{kWh} / \text { year for every CRT monitor } \\
\text { replaced with a LED backlit model }\end{array}$ & $100 x$ & & \\
\hline $\begin{array}{l}\text { Disable computer screen savers and enable the } \\
\text { power option settings to standby after } 15 \text { minutes. }\end{array}$ & $\square$ & $\square$ & $\square$ & $\begin{array}{l}75 \mathrm{kWh} / \text { year for every monitor with } \\
\text { standby options enabled }\end{array}$ & $75 x$ & & \\
\hline \multicolumn{8}{|l|}{ Printer } \\
\hline Replace laser printer with ink jet/ENERGY STAR. & $\square$ & $\square$ & $\square$ & \begin{tabular}{|l|}
$165 \mathrm{kWh} /$ year for every laser printer \\
replaced with an ink jet/ENERGY STAR model
\end{tabular} & $165 \mathrm{x}$ & & \\
\hline \multicolumn{8}{|l|}{ Lobby Television } \\
\hline $\begin{array}{l}\text { Replace standard TV with high-efficiency/ENERGY } \\
\text { STAR TV. }\end{array}$ & $\square$ & $\square$ & $\square$ & $\begin{array}{l}440 \mathrm{kWh} / \mathrm{year} \text { for each television that is } \\
\text { powered down nightly and on weekends }\end{array}$ & $440 x$ & & \\
\hline $\begin{array}{l}\text { Enable night and weekend shutdown of lobby TV } \\
\text { (daily shutdown } 12 \mathrm{pm} \text { to } 5 \mathrm{am} \text { ). }\end{array}$ & $\square$ & $\square$ & $\square$ & $\begin{array}{l}200 \mathrm{kWh} / \mathrm{year} \text { for each television that is } \\
\text { powered down nightly and on weekends }\end{array}$ & $200 x$ & & \\
\hline \multicolumn{8}{|l|}{ Computer CPU } \\
\hline Replace desktop computers with laptop computers. & $\square$ & $\square$ & $\square$ & $\begin{array}{l}250 \mathrm{kWh} / \text { year for each desktop com- } \\
\text { puter that is replaced with a laptop }\end{array}$ & $250 x$ & & \\
\hline $\begin{array}{l}\text { Replace desktop computers with high-efficiency/ } \\
\text { ENERGY STAR desktop computers. }\end{array}$ & $\square$ & $\square$ & $\square$ & $\begin{array}{l}135 \mathrm{Kwh} / \text { year for each desktop comput- } \\
\text { er replaced with an ENERGY STAR model }\end{array}$ & $135 \mathrm{x}$ & & \\
\hline $\begin{array}{l}\text { Enable night and weekend shutdown of existing } \\
\text { desktop computers (daily shutdown } 8 \text { pm to } 5 \mathrm{am} \text { ). }\end{array}$ & $\square$ & $\square$ & $\square$ & $\begin{array}{l}150 \mathrm{KWh} / \text { year for each computer with } \\
\text { night and weekend shutdown enabled }\end{array}$ & $150 x$ & & \\
\hline \multicolumn{8}{|l|}{ Computer Monitor } \\
\hline Replace CRT monitors with LED backlit monitors. & $\square$ & $\square$ & $\square$ & $\begin{array}{l}100 \mathrm{kWh} / \text { year for every CRT monitor } \\
\text { replaced with a LED backlit model }\end{array}$ & $100 x$ & & \\
\hline $\begin{array}{l}\text { Disable computer screen savers and enable the } \\
\text { power option settings to standby after } 15 \text { minutes. }\end{array}$ & $\square$ & $\square$ & $\square$ & $\begin{array}{l}75 \mathrm{kWh} / \text { year for every monitor with } \\
\text { standby options enabled }\end{array}$ & $75 x$ & & \\
\hline \multicolumn{8}{|l|}{ Printer } \\
\hline Replace laser printer with ink jet/ENERGY STAR. & $\square$ & $\square$ & $\square$ & $\begin{array}{l}165 \mathrm{kWh} / \text { year for every laser printer } \\
\text { replaced with an ink jet/ENERGY STAR model }\end{array}$ & $165 \mathrm{x}$ & & \\
\hline \multicolumn{8}{|l|}{ Multi-Function Devices } \\
\hline $\begin{array}{l}\text { Replace standard laser multi-function device with } \\
\text { ENERGY STAR. }\end{array}$ & $\square$ & $\square$ & $\square$ & $\begin{array}{l}105 \mathrm{kWh} / \text { year for each laser multi- } \\
\text { function device replaced with an ENERGY } \\
\text { STAR model }\end{array}$ & $105 \mathrm{x}$ & & \\
\hline $\begin{array}{l}\text { Enable night and weekend shutdown of multi-func- } \\
\text { tion device (daily shutdown } 8 \mathrm{pm} \text { to } 5 \mathrm{am} \text { ) }\end{array}$ & $\square$ & $\square$ & $\square$ & $\begin{array}{l}90 \mathrm{kWh} / \text { year for each multi-function } \\
\text { device with night and weekend shutdown } \\
\text { enabled }\end{array}$ & $90 x$ & & \\
\hline
\end{tabular}




\begin{tabular}{|c|c|c|c|c|c|c|c|}
\hline \multirow[b]{2}{*}{ Strategies } & \multicolumn{3}{|c|}{$\begin{array}{c}\text { Is your } \\
\text { building } \\
\text { doing this? }\end{array}$} & \multicolumn{4}{|c|}{$\begin{array}{l}\text { If you answered "NO," fill out these columns to determine the approximate savings } \\
\text { in your building }\end{array}$} \\
\hline & YES & NO & N/A & \multicolumn{2}{|c|}{$\begin{array}{l}\text { Savings for } 1 \text { Piece of Equipment } \\
\text { in } \mathrm{kWh} / \text { year saved }\end{array}$} & $\begin{array}{l}\text { Quantity in } \\
\text { Your Building }\end{array}$ & $\begin{array}{l}\text { Total Approx. Savings } \\
\text { for Your Building } \\
\end{array}$ \\
\hline \multicolumn{8}{|l|}{ Conference Rooms } \\
\hline \multicolumn{8}{|l|}{ Computer CPU } \\
\hline Replace desktop computers with laptop computers. & $\square$ & $\square$ & $\square$ & $\begin{array}{l}250 \mathrm{kWh} / \text { year for each desktop com- } \\
\text { puter that is replaced with a laptop }\end{array}$ & $250 x$ & & \\
\hline $\begin{array}{l}\text { Replace desktop computers with high-efficiency/ } \\
\text { ENERGY STAR desktop } \\
\text { computers. }\end{array}$ & $\square$ & $\square$ & $\square$ & $\begin{array}{l}135 \mathrm{kWh} / \mathrm{year} \text { for each desktop comput- } \\
\text { er replaced with an ENERGY STAR model }\end{array}$ & $135 x$ & & \\
\hline $\begin{array}{l}\text { Enable night and weekend shutdown of existing } \\
\text { desktop computers (daily shutdown } 8 \text { pm to } 5 a m \\
\text { and all day Sunday). }\end{array}$ & $\square$ & $\square$ & $\square$ & $\begin{array}{l}180 \mathrm{kWh} / \text { year for each computer with } \\
\text { night and weekend shutdown enabled }\end{array}$ & $180 x$ & & \\
\hline \multicolumn{8}{|l|}{ Computer Monitor } \\
\hline Replace CRT monitors with LED backlit monitors. & $\square$ & $\square$ & $\square$ & $\begin{array}{l}100 \mathrm{kWh} / \text { year for every CRT } \\
\text { monitor replaced with a LED backlit model }\end{array}$ & $100 x$ & & \\
\hline $\begin{array}{l}\text { Disable computer screen savers and enable the } \\
\text { power option settings to standby after } 15 \text { minutes. }\end{array}$ & $\square$ & $\square$ & $\square$ & $\begin{array}{l}75 \mathrm{kWh} / \text { year for every } \\
\text { monitor with standby options enabled }\end{array}$ & $75 x$ & & \\
\hline \multicolumn{8}{|l|}{ Break/Lunch Rooms } \\
\hline \multicolumn{8}{|l|}{ Refrigerator } \\
\hline $\begin{array}{l}\text { Replace standard refrigerators with most efficient/ } \\
\text { ENERGY STAR (full size) model. }\end{array}$ & $\square$ & $\square$ & $\square$ & $\begin{array}{l}400 \mathrm{kWh} / \text { year for each inefficient refrig- } \\
\text { erator replaced by an ENERGY STAR model }\end{array}$ & $400 x$ & & \\
\hline \multicolumn{8}{|l|}{ Vending Machine } \\
\hline $\begin{array}{l}\text { Replace standard refrigerated vending machines } \\
\text { with most efficient ENERGY STAR model. }\end{array}$ & $\square$ & $\square$ & $\square$ & $\begin{array}{l}\text { 1,500 } \mathbf{k W h} / \text { year for each vending } \\
\text { machine that is replaced with most efficient } \\
\text { ENERGY STAR model }\end{array}$ & $1,500 x$ & & \\
\hline Remove underused refrigerated vending machines. & $\square$ & $\square$ & $\square$ & $\begin{array}{l}\text { 3,500 } \mathbf{k W h} / \text { year for each vending } \\
\text { machine that is removed }\end{array}$ & $3,500 x$ & & \\
\hline Install occupancy-based load management device. & $\square$ & $\square$ & $\square$ & $\begin{array}{l}950 \mathrm{kWh} / \text { year for each vending machine } \\
\text { with an occupancy-based load management } \\
\text { device installed }\end{array}$ & $950 x$ & & \\
\hline Remove vending machine display lighting. & $\square$ & $\square$ & $\square$ & $\begin{array}{l}650 \mathrm{kWh} / \text { year for each vending machine } \\
\text { with an occupancy-based load management } \\
\text { device installed }\end{array}$ & $650 x$ & & \\
\hline \multicolumn{8}{|l|}{ Guest Rooms } \\
\hline \multicolumn{8}{|l|}{ Television } \\
\hline $\begin{array}{l}\text { Replace standard TV with high-efficiency/ENERGY } \\
\text { STAR TV. }\end{array}$ & $\square$ & $\square$ & $\square$ & $\begin{array}{l}150 \mathrm{kWh} / \mathrm{year} \text { for each inefficient refrig- } \\
\text { erator replaced by an ENERGY STAR model }\end{array}$ & $150 x$ & & \\
\hline $\begin{array}{l}\text { Replace standard guestroom compact refrigerators } \\
\text { with most efficient ENERGY STAR model }\end{array}$ & $\square$ & $\square$ & $\square$ & $\begin{array}{l}70 \mathrm{kWh} / \text { year for every guest room com- } \\
\text { pact refrigerator that is replaced }\end{array}$ & $70 x$ & & \\
\hline \multicolumn{8}{|l|}{ Common Areas and Hallways } \\
\hline \multicolumn{8}{|l|}{ Vending Machine } \\
\hline $\begin{array}{l}\text { Replace standard refrigerated vending machines } \\
\text { with most efficient ENERGY STAR model. }\end{array}$ & $\square$ & $\square$ & $\square$ & $\begin{array}{l}\text { 1,500 } \mathrm{kWh} / \text { year for each vending } \\
\text { machine that is replaced with most efficient } \\
\text { ENERGY STAR model }\end{array}$ & $1,500 x$ & & \\
\hline Remove underused refrigerated vending machines. & $\square$ & $\square$ & $\square$ & $\begin{array}{l}\text { 3,500 } \mathrm{kWh} / \mathrm{year} \text { for each vending } \\
\text { machine that is removed }\end{array}$ & $3,500 x$ & & \\
\hline Install occupancy-based load management device. & $\square$ & $\square$ & $\square$ & $\begin{array}{l}950 \mathrm{kWh} / \mathrm{year} \text { for each vending machine } \\
\text { with an occupancy-based load management } \\
\text { device installed }\end{array}$ & $950 x$ & & \\
\hline Remove vending machine display lighting. & $\square$ & $\square$ & $\square$ & $\begin{array}{l}650 \mathrm{kWh} / \text { year for each vending machine } \\
\text { with an occupancy-based load management } \\
\text { device installed }\end{array}$ & $650 x$ & & \\
\hline
\end{tabular}




\begin{tabular}{|c|c|c|c|c|c|c|c|}
\hline \multirow[b]{2}{*}{ Strategies } & \multicolumn{3}{|c|}{$\begin{array}{l}\text { Is your } \\
\text { building } \\
\text { doing this? }\end{array}$} & \multicolumn{4}{|c|}{$\begin{array}{l}\text { If you answered "NO," fill out these columns to determine the approximate savings } \\
\text { in your building }\end{array}$} \\
\hline & YES & NO & N/A & $\begin{array}{l}\text { Savings for } 1 \text { Piece of Equi } \\
\text { in } \mathrm{kWh} / \text { year saved }\end{array}$ & & $\begin{array}{l}\text { Quantity in } \\
\text { Your Building }\end{array}$ & $\begin{array}{l}\text { Total Approx. Savings } \\
\text { for Your Building }\end{array}$ \\
\hline \multicolumn{8}{|l|}{ Ice Machine } \\
\hline $\begin{array}{l}\text { Replace standard ice machine with most efficient } \\
\text { ENERGY STAR model. }\end{array}$ & 口 & 口 & $\square$ & $\begin{array}{l}330 \mathrm{kWh} / \mathrm{year} \text { for each vending machine } \\
\text { with an occupancy-based load management } \\
\text { device installed }\end{array}$ & $330 x$ & & \\
\hline \multicolumn{8}{|c|}{ Non Quantified/Application Specific Opportunities } \\
\hline \multicolumn{8}{|c|}{ Network/Server Rooms } \\
\hline $\begin{array}{l}\text { Replace standard servers with high-efficiency blade } \\
\text { servers }\end{array}$ & $\square$ & 口 & 口 & & & & \\
\hline $\begin{array}{l}\text { Replace standard uninterruptable power supplies } \\
\text { (UPS) with 95\% efficient UPS }\end{array}$ & 口 & 口 & 口 & & & & \\
\hline $\begin{array}{l}\text { Replace other ancillary equipment (computers, } \\
\text { monitors, etc.) with ENERGY STAR or better }\end{array}$ & $\square$ & 口 & 口 & & & & \\
\hline \multicolumn{8}{|l|}{ Miscellaneous } \\
\hline $\begin{array}{l}\text { Small cooking and heating appliances/coffee makers. } \\
\text { Use electrical timers or controlled breakers to power } \\
\text { down appliance and equipment during off-hours. }\end{array}$ & 口 & 口 & 口 & & & & \\
\hline $\begin{array}{l}\text { Pools and Hot Tubs. Cover all pools and hot tubs } \\
\text { after hours to minimize heat loss }\end{array}$ & 口 & 口 & 口 & & & & \\
\hline $\begin{array}{l}\text { Housekeeping procedures. Encourage/incentive all } \\
\text { housekeeping staff to turn off all appliance and light- } \\
\text { ing when spaces are unoccupied }\end{array}$ & 口 & 口 & 口 & & & & \\
\hline $\begin{array}{l}\text { Implement management policies to minimize or } \\
\text { eliminate use of personal electronic equipment } \\
\text { (personal coffee makers, fans, heaters, mini-refriger- } \\
\text { ators, decorative lighting, etc.) }\end{array}$ & 口 & 口 & 口 & & & & \\
\hline $\begin{array}{l}\text { Educate employees on program goals and impor- } \\
\text { tance of their role, e.g., impacts of turning off equip- } \\
\text { ment when it is not in use. }\end{array}$ & 口 & 口 & 口 & & & & \\
\hline
\end{tabular}

\begin{tabular}{|c|c|c|}
\hline TOTAL ENERGY SAVINGS & $\begin{array}{c}\text { Add up the estimated energy } \\
\text { savings for all devices. }\end{array}$ & $\mathrm{kWh} /$ year \\
\hline TOTAL DOLLAR SAVINGS & $\begin{array}{c}\text { Multiply the average electric- } \\
\text { ity rate of the location by the } \\
\text { estimated energy savings. }\end{array}$ & $\$ /$ year \\
\hline TOTAL PORTFOLIO DOLLAR & $\begin{array}{c}\text { Determine the number of sites } \\
\text { the estimated energy savings } \\
\text { could apply to and multiply } \\
\text { that by the total dollar savings. }\end{array}$ & $\$ /$ year \\
\hline
\end{tabular}




\section{(Endnotes)}

'The ENERGY STAR and EPEAT programs maintain databases of energy efficient equipment. ENERGY STAR is a joint program of the U.S. Environmental Protection Program and the U.S. Department of Energy targeting energy efficiency and environmental stewardship. EPEAT (Electronic Product Environmental Assessment Tool) is a web based tool helping institutional purchasers select and compare computer desktops, laptops, and monitors based on their environmental attributes.

\section{References}

CBECs 2003. Commercial Buildings Energy Consumption Survey 2003. Energy Information Administration, Washington DC.

Deru, M.; Torcellini, P.; Bottom, K.; Ault, R., 2003. Analysis of NREL Cold-Drink Vending Machines for Energy Savings. Golden, CO: National Renewable Energy Laboratory. NREL/TP-550-34008 wWw.nrel.gov/docs/fy03osti/34008.pdf.

ECOS 2011. Office Plug Load Field Monitoring Report. Prepared for the California Energy Commision - Public Interest Research Program. CEC-500-2011-010. ECOS Portland, OR.

Esource 2008. Managing Office Plug Loads. Energy Manager's Quarterly. June 2008. Has reference to "Space Heaters, Computers, Cell Phone chargers: How Plugged in are Commercial Buildings?” LBNL - 62397

Frank, S.; Lobato, C.; Long, N.; Gentile Polese, L.; Rader, E.; Sheppy, M.; Smith, J., 2010. Monitoring and Characterization of Miscellaneous Electrical Loads in a Large Retail Environment. Golden, CO: National Renewable Energy Laboratory, NREL/TP-5500-50044. To be published April 2011.

Lobato, C.; Pless, S.; Sheppy, M., 2011. Reducing Plug and Process Loads for a Large Scale, Low Energy Office Building: NREL's Research Support Facility. Golden, CO: National Renewable Energy Laboratory. NREL/CP-5500-49002. www.nrel.gov/docs/fy11osti/49002.pdf.

McKenney, K.; Guernsey, M.; Ponoum, R.; Rosenfeld, J., 2010. Commercial Miscellaneous Electric Loads: Energy Consumption Characterization and Savings Potential in 2008 by Building Type. Lexington, MA: TIAX LLC. May. http://zeroenergycbc.org/pdf/2010-05-

26 TIAX CMELs Final Report.pdf.

NREL 2011. Assessing and Reducing Plug and Process Loads in Office/Retail Buidlings. Draft DOE Documents.

Navigant Consulting 2009. Energy Savings potential and RD\&D Opportunities for Commercial Building Applicances. Final Report, US DOE, EERE, OBT. December 21, 2009

TIAX 2004. Energy Consumption by Office and Telecommunications Equipment in Commercial Buildings. TIAX D0065-11.08

\section{Resources}

ENERGY STAR Purchasing Specifications. ENERGY STAR is a joint program of the U.S. Environmental Protection Agency and the U.S. Department of Energy focused on saving energy, money and helping to protect the environment through energy efficient products and practices. ENERGY STAR has series of electronic tools and product specifications targeting the highest efficiency commercially available products. This set of tools and specifications can be found at: http://www.energystar.gov/

Federal Energy Management Program (FEMP) Purchasing Specifications. FEMP has developed a set of electronic tools for specifying energy-efficient products that are organized by major category and product type. This set of tools can be found at: http://www1.eere.energy. gov/femp/technologies/eep_purchasingspecs.html

Consortium for Energy Efficiency (CEE). CEE is a nonprofit public benefits corporation that develops initiatives to promote the manufacture and purchase of energy-efficient products and services. CEE promotes and supports a number of appliance and equipment efficiency efforts and provides extensive lists of high-efficiency-qualifying products. These product categories and lists can be found at: http://www. ceel.org/

Jiang W, K Gowri, MD Lane, BA Thornton, MI Rosenberg, and B Liu. 2009. Technical Support Document: 50\% Energy Savings Design Technology Packages for Highway Lodging Buildings. PNNL-18773, Pacific Northwest National Laboratory, Richland, WA. 


\section{ve ENEROY}

Energy Efficiency \& Renewable Energy
EERE Information Center

1-877-EERE-INF (1-877-337-3463)

www.eere.energy.gov/informationcenter

For more information, visit:

commercialbuildings.energy.gov/alliances
Commercial Building Initiative 